\title{
scripted
}

Volume 14, Issue 2, December 2017

\section{Book review: The End of Ownership: Personal Property in the Digital Economy}

\author{
Aaron Perzanowski and Jason Schultz \\ Cambridge, Mass.: MIT Press, 2016. 249 pages. ISBN 9780262035019. \\ $£ 24.95$.
}

Reviewed by Argyro P. Karanasiou*

(ㄷ) (1) $\circledast \Theta$

(C) 2017 Argyro P. Karanasiou

Licensed under a Creative Commons Attribution-NonCommercial-

NoDerivatives 4.0 International (CC BY-NC-ND 4.0) license

DOI: $10.2966 /$ scrip.140217.401

\footnotetext{
* Senior Lecturer in Law, Law Department, Bournemouth University, Bournemouth, United Kingdom, akaranasiou@bournemouth.ac.uk
} 
...where a man has purchased an article he expects to have control of it, and there must be some clear and explicit agreement to the contrary to justify the vendor in saying that he has not given the purchaser his license to sell the article or to use it wherever he pleases as against himself.

(Betts v Willmott, 1871, 6 LR Ch App 239, 245)

Lord Hatherley's L.C. ruling in the leading case of Betts $v$ Willmott, although dating back to 1871, appears to be at the heart of the argument explored in this book, co-authored by Aaron Perzanowski, Professor of Law at Case Western Reserve University, and Jason Schultz, Professor of Clinical Law at New York University (NYU) School of Law and Director of NYU's Technology Law and Policy Clinic. The book appears to be an elaboration of the authors' earlier works, mainly on digital exhaustion. ${ }^{1}$ As such, it provides a theoretical exploration that revolves around the exhaustion principle ${ }^{2}$ and the potential it holds to maintain "property as a smart policy" in the digital economy (p. 33). It is not until the final chapter, however, that another underlying key theme is further revealed: the "end of ownership" and the shift towards a licence-driven regime within the context of the "shared economy" business model. This is indeed a timely and accurate observation that succinctly summarises the challenges posed for a property based system: you might no longer own a car or a house, but you are able to only use this on a "pay-as you go" basis, through your subscription with Uber or AirBnB.

1 Aaron Perzanowski and Jason Schultz, "Copyright Exhaustion and the Personal Use Dilemma" (2012) 96 Minnesota Law Review 2067-2143; Aaron Perzanowski and Jason Schultz, "Reconciling Intellectual and Personal Property" (2015) 90 Notre Dame Law Review 1211-1264; Aaron Perzanowski and Jason Schultz, "Digital Exhaustion" (2011) 58 UCLA Law Review 889946.

2 The exhaustion doctrine is an accepted limitation to intellectual property rights, namely once a given product has been sold under the authorisation of the IP owner, the owner can no longer control the distribution or resale of the product. The owner's IP rights are said to be "exhausted". 
This book can be divided in three major parts. First, Chapters 1, 2 and 3 are intended to set the scene for the reader and explain the narrower scope of property in the digital economy. In the remainder of the book, the authors do a great job at explaining the legal (Chapters 4, 5, 6 and 9) and technological limitations (Chapters 7 and 8) that are imposed on the idea of "digital ownership", which leads to the third part (Chapter 10), namely the concluding remarks and a few suggestions towards reinstating the notion of "property" in the digital era. In what follows, I highlight specific parts of the book that demonstrate both rigour and weakness in argument.

Chapter 2 introduces the reader to the main concepts that underpin the core argument put forth here: property, as a key theme that can support the consumer's expectations in the digital economy while retaining the ability to internalise externalities. ${ }^{3}$ The property rhetoric followed here is not an absolutist one, although there are still certain risks lurking that are not fully addressed, such as the incentives and access trade-off as a booster for digital economy. ${ }^{4}$

Chapters 4 and 5 draw heavily from a paper by Perzanowski and Hoofnagle, ${ }^{5}$ which provides empirical evidence and seeks to understand how if at all - a consumer's preferences are shaped by the limited information she receives; contrary to her experience under the traditional "ownership status" from past (offline) purchases, what follows an online purchase is a restricted ("contingent") access to digital goods/services. Chapter 5 in particular maintains a strong focus on how deceptive means can redefine the concept of "property"

3 Harold Demsetz, "Toward a Theory of Property Rights" (1967) 57(2) The American Economic Review 347-359.

4 Mark Lemley, "Property, Intellectual Property, and Free Riding" (2004) 83 Texas Law Review 1031-1075; Julie Cohen, "Copyright and the Perfect Curve" (2000) 53 Vanderbilt Law Review 1799-1819, pp. 1801-03.

5 Aaron Perzanowski and Chris Jay Hoofnagle, “What We Buy When We 'Buy Now'” (2017) 165(2) University of Pennsylvania Law Review 315-378. 
inasmuch e.g. vague End User License Agreements (EULAs) are capable of misinforming the average consumer and shape expectations accordingly. The empirical data provided in the study "MediaShop" gives an accurate account of the consumer's understanding of the basic legal entitlements transferred through a transaction and is reminiscent of similar marketing studies using computersimulated environments to explain consumer behaviour. ${ }^{6}$ While this is a valuable tool in configuring means of preventing consumer deception, Chapter 5 concludes with a rather ambiguous note, adding that "even highly sophisticated and informed digital media shoppers, cannot avoid the constraints that law, license and technology impose" (p. 101).

The latter proposition is at large a summary of the authors' suggestions towards reinforcing consumer's choice with regards to a widened scope of "property" in the digital economy (pp. 173-191): limitation of contractual and machine-code restrictions, a broader definition of the exhaustion principle in copyright and patent law, as well as embracing decentralised architectures employed in cryptocurrencies. The latter is seen as a way to reinstate trust in transactions and support a sustainable environment for digital single property. Ultimately, the authors argue that the sharing economy model lacks the clarity, certainty and public values that a property-based system can offer. This assertion, however, is not further supported with references to political economy and as such remains fairly open-ended.

There are certainly parts of this book that provide some interesting arguments and do succeed in highlighting well what is at risk when the consumer is willing to trade off ownership for access. One such example is the references to the Internet of Things (IoT) (Chapter 8), which informs nicely the

6 See e.g. Marios Koufaris, "Applying the Technology Acceptance Model and Flow Theory to Online Consumer Behavior" (2002) 13(2) Information Systems Research 205-223. 
concluding part of this book and provides the reader with scenarios that demonstrate the limitations in the consumer's use of purchased goods and services:

Imagine your reasonably-hip crossover vehicle alerting you after your third after-school, stop, “I'm sorry; you 've reached your limit of daily passenger drop-offs. Would you like to upgrade your vehicle plan to CarPoorPro?" As if that weren't indignity enough your carmaker's pricing algorithm - relying on information it has gathered about property values in your neighbourhood, your driving patterns, and your in-car search history predicts exactly how much you are willing to pay for the privilege of dropping off that last cranky first grader. This is exactly the goal of the price and geographic discrimination tactics we have discussed throughout the book - to divide our lives into individual transactions and charge as much as we are willing to pay for each one. (p. 172).

This is indeed an accurate observation that summarises well how smart devices employing opaque algorithms are able to utilise all user-related data to downgrade the consumer's bargaining position in negotiating for rights transferred through a purchase. At the same time, although the authors condemn a mostly compartmentalised understanding of ownership, they do not look further into the depreciation of the property's value (frequently referred to as the "moral hazard" issue in economics), which is most certainly affecting property rights in turn. ${ }^{7}$ Also, in building a US-focused argument, the authors do not benefit from the lessons the EU jurisprudence might have to teach. Take, for example, Chapter 9, which could be further explored in the light of the ECJ ruling

7 Arun Sundararajan, The Sharing Economy: The End of Employment and the Rise of CrowdBased Capitalism (Cambridge, Mass.: MIT Press, 2016). 
in Centrafarm $v$ Sterling Drug (C-15/74), the leading case on exhaustion of patent rights or Deutsche Grammophon v Metro on copyright exhaustion (C-78/70). In this vein, the frequent references to the United States Supreme Court copyright decision of Kirtsaeng ${ }^{8}$ throughout the book could lead into a deeper analysis taking into consideration EU's approach on the matter, where the position, as reflected in the CJEU decision of Laserdisken (C-479/04) in 2006, is that international exhaustion does not apply to the distribution rights within the EU.

I remain somewhat sceptical that a clearer defined concept of ownership, in light of the exhaustion principle, would be enough to pave the road towards a consumer-centric regulative framework in the digital market. The ample references in the book to certain rapidly evolving digital services and goods, such as automated systems, IoT, and wearable technology, certainly explain well the limited choices reserved for the consumer. Yet in a global digital market, the potential for US copyright reform, supported further by encrypted transactions, is not enough to guarantee the reinforcement of property rights for allowing meaningful choices for consumers.

$8 \quad$ Kirtsaeng $v$ John Wiley E Sons, Inc., 568 U.S. 519, 133 S. Ct. 1351 (2013). 